\title{
The Issue of Low Carbon Emission in Religious Shows on Indonesian Television
}

\author{
Amirudin Amirudin ${ }^{1 *}$ \\ ${ }^{1}$ Department of Anthropology, Faculty of Humanities, Diponegoro University, 50275 Indonesia
}

\begin{abstract}
This Article is written based on the research "Religious Show as Cultural Production Field: Study of Mamah dan Aa Beraksi TV program on Urban Indonesian TV Channel Indosiar". This research based on assumption that religious show as cultural products are generated in an autonomous domain involving actors - production teams, creative teams, preachers, emcees and audiences. Using ethnographic methods, through close observation, this research finds that the religious show indicate the logic interpretation of religious criteria represented by the preachers, and the market criteria which the production team is responsible for. Both of these criteria are mixed in producing religious show. On that context, the theme of low carbon emission has succeeded in entering as a theme that meets market and religious criteria. From the market side, this theme has relevance with the protection of a greater public interest. Meanwhile, in terms of religious criteria, bringing the issue of low carbon emission into religious shows is the same as carrying out a religious mission to reduce the negative impact of bubble carbon.
\end{abstract}

Keywords: Urban Indonesian Television, Low Carbon Emission, Religious Show

\section{Introduction}

This research begins from the question of religious show production process Mamah dan Aa Beraksi on Indosiar Television Station - one of the popular urban TV channel in Indonesia - in relation to the culture's formation [1-4]. The research is a holistic study which focus on the dynamics relations between actors in religious show production process in the studio as cultural production field. This holistic study is intended to reveal the image of each actor associated with the production process of the show in cultural production field. The imagery in the production of the show is positioned as an entity connecting the existing production process in the studio to the social reality outside the studio.

Many studies on media and cultural production have been conducted, among others are Novenanto and Irianto studies [5-6]. However, these two studies have not yet addressed the dynamics of the creative process of television production. The dynamics are not just contestation arising from the various political economic interests, but how the interrelated interests can be imaginatively consolidated in a show [7]. The displayed shows are in essence the imagination of accommodation of various interests.

Based on Bourdieu's perspective, this study aims to see how the creative team, in producing television, imagines and connects themselves to accommodate a number of interests from various parties [8-9]. A number of interests which include: the interest to meet the audiences' interest, and television owners interest to see their channel to be a favorite channel and result in gaining more advertising revenue.

\section{Methods}

This research was conducted in Indosiar TV studio, specifically when producing religious show Mamah Dedeh and Aa Beraksi which aired every day at 06:00 07:30 WIB. Using ethnographic methods, researchers conducted close observations ranging from preproduction, during production, to post-production.

\section{Results and Discussion}

Ronald Lukens-Bull provides an observation of the symptoms of religious presence in the era of globalization. According to him, production, consumption and image contestation is not just a product of globalization, but also a response to the globalization [10]. At this point, the process of commodification and ideologization through images meets and shapes each other. The late capitalism, according to Lukens-Bull, "can involve both the ideologicalization of commodities and the commoditization of ideologies". Religion, as one of the form of ideology, appears as a force that forms commodities, not merely as passive objects formed by the commodification process of all the lines of life that characterize the globalization market. In other words,

\footnotetext{
* Corresponding author amdjtg@yahoo.com
} 
what happens is not just "commodification of religion", but also "religiosity of commodity".

Close observations of religious shows such as Mamah and Aa Beraksi show us how the commodification and its religious processes met. The criteria of market commodities and religious criteria is combined each other succesfully, so it will be difficult to conclude that either religion is dominating the public arena that so-called market, or the religion has been conquered by the market. The reality in the production field is not that simple. 'Religious' actors and 'commodity' are interactively processed; they influence each other, and on many occasions can veto each other.

It is true that as a product assessed by the market, religious show such as Mamah dan Aa Beraksi did not escape the commodity laws that have a certain standard. The show's visuality is clearly showing that the preacher should come up with clothes in harmony with the overall setting. The preacher should also be willing to touch up. These things may not be done as Mamah Dedeh's habit in life outside the production process. Similarly, the audience involved. They will inevitably have to be uniformed with matching the color of the clothes and the pattern of the hijab. The yells and special movements of live audiences are also specified for the show packaging to suit the tastes of the market.

However, on the other hand, these visual displays are viewed only as a "tool" for Mamah Dedeh and his team to preach religion to society. The "market standard" applied in the visual display is not seen as a form of "religion conquesting", because there are also standard criteria based on religion followed, as manifested in the costume that must meet the standards of "Muslim clothing". At this point, religious criteria can be considered to win the battle when it is able to make the commercial arena adopt religious rules in dress. Both the preacher and woman-attendants as live audiences wear clothes according to religious criteria like what they used in Islamic studies in mosques. Here there are only color differences and uniformity. This may be referred to as a form of symmetrical interpenetration: religion penetrates the market by allowing markets to penetrate religion.

Another interesting example is related to the question that came from email. From ethnographic aspect, we know that not all the questions really came from real audiences. The production team sometimes needs to make "improvisation" by creating a "fake" email containing questions to Mamah Dedeh. The reason because either there is no question comes from email, or there is a question but it is less suitable with the theme of the discussion. In terms of market criteria, questions from these emails are needed to create an interactive and present impression. However, in terms of religious criteria, such practices may be considered as violation to the value of honesty or can be judged as a form of fraud. However, it seems that Mamah Dedeh's team, as the guardian of religious standards in the show, is not very concerned. It means the market penetration to religion realm is not a problem as far as it is seen as a tool to deliver da'wah.
Furthermore, religious and market criteria are not able to fully control the overall practice that arises in the production arena. Many small actions and expressions are outside the corridors of religion as well as the market. The most notable example is Mamah Dedeh's laugh. In terms of market orientation, it is difficult to say that Mamah Dedeh's laughter style is formed by commercial etiquette, even at a certain point it is arguably deviate from commercial law, not elegant and crashing. In terms of religious it is also viewed as less proper. Conventional religious advice assumes that women must be able to control the way of speaking, moreover their way of laughing - not to mention the performer is an ustadzah like Mamah Dedeh who is assumed to be an exemplary figure. However, the religious convention also appears to be less concerned.

The issue of climate change and low carbon emission green growth has also become part of television attention because of its adverse effects in terms of economic, social and environmental aspects. Since the Paris Agreement in 2015, the world is required to limit the use of carbon so that the earth's temperature does not increase by 2 degrees Celsius. This limitation is needed so that the impacts of climate change can be reduced.

Dealing with climate change, the energy sector investment often forgets to take into account the "Carbon Bubble", which is the total amount of earth's energy potential as much as 2795 billion tons of $\mathrm{C} 02$, but on the one hand the maximum quota of carbon use per year 2050 is 565 billion tons of CO2. This will affect the investment valuation in the energy sector after 2050. Indonesia will also face the same carbon bubble. The Government, with the National Energy Policy Roadmap, starts to invest in low carbon emission or sustainable energy. On the other hand, with increasingly advanced technology, palm oil will replace the role of biofuels and fossil fuels because $99 \%$ can be converted into new sources of energy.

This certainly needs to be watched out and anticipated through strategic national policies. With the European parliamentary resolution to ban biofuel exports in 2020, Indonesia needs to map an implementative energy policy strategy. In principle, Indonesia's energy security is strong enough to reach 2050.

Indonesia's energy needs continue to grow along with the existing infrastructure development. It is time for stakeholders of the government, the private sector, and television to pay attention to the carbon bubble and make this issue a special concern, especially in regulating domestic energy investment, limiting the opening of new mines, as well as incentives for technological advances in sustainable energy.

In the context production of the religious shows, a theme such as low carbon emission has also been successfully accepted into an issue that meets the criteria of the market and religion. From the market side, this theme has relevance with the protection of the public interest. Meanwhile, in terms of religious criteria, On that context, the theme of low carbon emission has succeeded in entering as a theme that meets market and 
religious criteria. From the market side, this theme has relevance with the protection of a greater public interest. Meanwhile, in terms of religious criteria, bringing the issue of low carbon emission into religious shows, is the same as carrying out a religious mission to reduce the negative impact of bubble carbon.

Therefore, discussing low carbon emission through religious shows on television needs to be continued, not only once or twice but many times because this theme in market and religious criteria has been accepted

\section{Conclusion}

In addition, commodification and religiosity do not totally reach the whole practice in the production arena. For Bourdieu, each domain implies a different habit [9]. However, not all actors have the same trajectory in accumulating cultural capital when entering or exiting from a certain realm. That is, within a domain, there might appear an expression of actors emerging from the core of the game. There is no total incorporation, the individual still has a disposition built through his socialization history outside the production arena. It is reasonable if the expressions and actions appeared in accordance with the structure of action in the realm. There, the contradiction becomes possible. An expression or action may be inconsistent with religious criteria as well as market criteria, but still present coloring the game.

In this context, the theme of low carbon emission has succeeded in entering as a theme that meets market and religious criteria. From the market side, this theme has relevance with the protection of a greater public interest. Meanwhile, in terms of religious criteria, bringing the issue of low carbon emission into religious shows, is the same as carrying out a religious mission to reduce the negative impact of bubble carbon.

Moreover, referring to Turner, and V. B. Mayer, if the whole practice of actors in a show is seen as a game, then the game is actually a form of "cultural show" which allows for the flexing of rules, improvisations, and even contradictions [11-12].

\section{Acknowlegments}

Due to the completion of scientific research and publication, I would like to thank to Prof. Dr. Yos Johan Utama, Rector and Dr. Redyanto Noor, Dean of
Humanities Faculty of the Diponegoro University, and also the Director of Indosiar TV Channel, for providing support and facilitation for implementation of research and publication. Their Support makes this scientific work accomplished.

\section{Reference}

1. T. Gunter. 'The Emergence of Religious Forms on Television', dalam Eric W. Rotheonbuhler and Mihai Coman (eds): Media Anthropology (London: Sage Publication. pp. 77-88. 2006).

2. P. Kitiarsa. 'Religious Commodifications in Asia', in Pattana Kitiarsa (ed): Religious Commodifications in Asia: Marketing Gods. (Routledge. New York. p.1-13. 2008).

3. Abu-Lughod, Ginsburg, and Larkin B., Media Worlds: Anthropology on New Terrain. (University of California Press. Berkeley. 2002).

4. W. Mazzarella,. 'Culture Globalization, Mediation', in Annual Review of Anthropology. 33: 345-367. (2004)

5. A. Novenanto. Mediated Disaster: The Role of Alternative and Mainstream Media in the East Java Mud Vulcano Disaster. (MA Thesis in Department of Cultural Anthropology and Development Sociology. Leiden: University of Leiden. 2009).

6. A.M. Irianto. Kontestasi Kekuasaan Sajian Acara Televisi: Studi tentang Program Tayangan Infotainment. (Disertasi Doktoral Program Studi Antropologi Universitas Indonesia. Depok. 2008)

7. T.W, Adorno. The Culture Industry: Selected Essays on Mass Culture, J. Bernstein (ed). (Routledge. London. 1991)

8. P. Bourdieu. The Outline of a Theory of Practice, trans. R. Nice. (Cambridge University Press. Cambridge M.A. 1977).

9. P. Bourdieu. The Field of Cultural Production: Eassys on Art and Literature. (Columbia University Press. New York. 1993).

10. R. Lukens-Bull. "Commodification of Religion and The 'Religification' of Commodities: Youth Culture and Religious Identity", in Pattana Kitiarsa (ed): Religious Commodifications in Asia: Marketing Gods. (Routledge. London. p.220-234. 2008).

11. V. B. Mayer . 'Introduction to Production Studies', in V.B. Mayer, Miranda J., Caldwell, dan John T (Eds) Production Studies: Cultural Studies of Media Industries. (Routledge. New York. p1-5. 2009).

12. V.W. Turner. Dramas, Fields and Metaphors: Symbolic Action in Human Society. (Cornell University Press. Ithaca. New York. 1974). 